\title{
Tao-Klarceti Bölgesi Hristiyan Dini Mimarisi Plastik Bezemelerinde Orans Duruş Geleneği
}

\section{The Tradition of Orans Position in Plastic Decorations of Christian Religious Architecture in Tao-Klarceti Region}

\author{
Tahsin Korkut \\ Dr. Öğr. Üyesi, Van Yüzüncü Yıl Üniversitesi Edebiyat Fakültesi Genel Sanat Tarihi Anabilim Dalı \\ email: t.korkut@yyu.edu.tr (DORCID ID: https://orcid.org/0000-0002-2888-662X
}

Atıf (APA 6)/To cite this article

Korkut, T. (2019). Tao-Klarceti bölgesi Hristiyan dini mimarisi plastik bezemelerinde orans duruş geleneği. Atatürk Üniversitesi Güzel Sanatlar Enstitüsü Dergisi, 43, 44-56. doi: https://doi.org/10.35247/ataunigsed.536972

Makale Gönderim Tarihi/Received: 07/03/2019

Makale Kabul Tarihi/Accepted: 24/09/2019

Makale Yayın Tarihi/Published: 26/10/2019

Research Article/Araştırma Makalesi

\section{$\ddot{O} z$}

Artvin ve Erzurum merkezli tarihi Tao-Klarceti bölgesi, 8. yy. dan 14.yy. a kadar Gürcü Bagratlı (Bagrationi) Krallığı'nın yönetim merkezi olmuştur. Bölgede 4. yy. dan itibaren yayılmaya bașlayan Hristiyanlıkla beraber halk, pagan inançları terk edip bu yeni dini kabullenmeye başlamıștır. 7-8. yy. den itibaren bölge dini mimarisi, Hristiyanlık temelinde manastırlar ve kiliseler olarak şekillenmeye başlamıştır. Tamara döneminde (12.yy. sonu-13. yy. başları) krallık her anlamda altın çağını yașamıș; bölgedeki bu dini mimari yapılara yenileri eklenmiş ve onarım gerektiren yapılarda restore edilmistir. Bagratlılar, Hristiyan gelenekleri konusunda, sınır komşuları olan ve dönemin güçlü devletlerinden Doğu Roma'dan (Bizans) beslenmişlerdir. Hıristiyan sanatında ikonografik anlamı olan Orans Duruş gibi birçok gelenek, TaoKlarceti mimarisinde de anlam bulmuştur. Dönemin güçlü sanatsal ifadesini yansıtan ender manastır kiliselerinden biri olan Öski Manastır Kilisesi'nde, Orans Duruşlu birçok sahne tespit edilmiştir. Başta melek figürleri olmak üzere, aziz ve azizeler ile kral tasvirlerinin orans duruş pozisyonunda sahnelendiği görülmektedir. $\mathrm{Bu}$ çalışmada, Tao-Klarceti Bölgesi taş bezemelerinde karșımıza çıan söz konusu bu orans duruş tasvirleri incelenmeye çalışılmıştır.

Anahtar kelimeler: Manastır Kilisesi, Kilise, Manastır, Bitkisel Bezeme, Hristiyan Mimarisi, Taş Süsleme, Orans.

\begin{abstract}
The historical Tao-Klarceti region centered between Artvin and Erzurum was the administrative centre of the Georgian Bagratian Kingdom from the 8 th century until the 14 th century. With the beginning of the spread of Christianity in the region since the 4th century, the people abandoned pagan beliefs and started to accept this new religion. From the 7 th and 8 th century onwards, the religious architecture of the region began to take shape of monasteries and churches on the basis of Christianity. During the Tamara period (late 12th and early 13th centuries), the kingdom experienced its golden age in every sense; new religious buildings were constructed in the region and those in need were restored. Bagratis, as to Christian traditions, were fed from Eastern Rome (Byzantine), the neighbour, one of the strongest powers of the period. Such many traditions as Orans Position having an iconographic meaning in Christian art, also found meaning in Tao-Klarceti architecture. There are many scenes with Orans Position in the Oski Monastery Church, one of the rare monastic churches that reflect the strong artistic expression of the period. The depictions of the saints and the kings, especially the angel figures, are staged in the orans position. The aim of this study is to analyze the depictions of the orans position in the stone decorations in Tao-Klarceti region.
\end{abstract}

Keywords: Abbey, Church, Monastery, Vegetable Decoration, Christian Architecture, Stone Ornament, Orans

\section{Giriş}

Orans (Orant), Latince "orare” (dua etmek) filinden türemiş olup, Hristiyan sanatında dua etme pozisyonundaki insan veya melek gibi figürler için kullanılan bir terimdir. Bu figürler genelde ayakta, kolları yukarı kalkmış olarak betimlenmektedir (Rona, 1997, s. 1172; Özdemiroğlu, 2010, s. 105). Günümüzde orans terimi, genel olarak Hristiyanlıkla ilişkilendirilirken; özü itibari ile pagan dönemlerde kullanılan dinsel bir imge olarak varlık göstermiştir. Biçimsel olarak orans duruş geleneğinin erken örnekleri Mısır, Hitit, Sümer, Girit ve Miken uygarlıklarında görülmektedir. Antik Mısır uygarlığının insanları, tanrıları Ra (Güneş Tanrısı) için, günü karşılarken yaptıkları dualarda; ellerini kaldırıp güneşi selamlamaktaydılar (Özdemiroğlu, 2010, s. 106). Orans duruşun bir başka erken dönem örneği; Antik Mezopotamya uygarlıklarında kabul gören ve dönemin (MÖ. 40002000) önemli tanrıçalardan biri olan aşk ve bereket Tanrıçası İnanna (İştar) figüründe görülmektedir. ${ }^{1}$ Günümüzde British Müzesi'nde teşhir edilen kabartmada; Tanrıça, dönemin kutsal sembolü olan adalet halkasını, başparmağı ile işaret parmağı arasında tutarak, oransa benzer bir biçimde tasvir edilmiştir (Görsel 1).

\footnotetext{
${ }^{1}$ Sümerlerde "İnanna”, Akadlardan itibaren Sami kökenli İştar adıyla tanınmaktadır. En önemli tapınağı Eanna (cennet evi) Uruk kentindeydi. İștar'ın kutsal hayvanı aslan, sembolü ise yıldızdı. Hammurabi dönemine ait bu kabartma $49 \mathrm{~cm}$ yüksekliğindedir. Daha detaylı bilgi için Bkz: Köroğlu, 2015, s. 110
} 


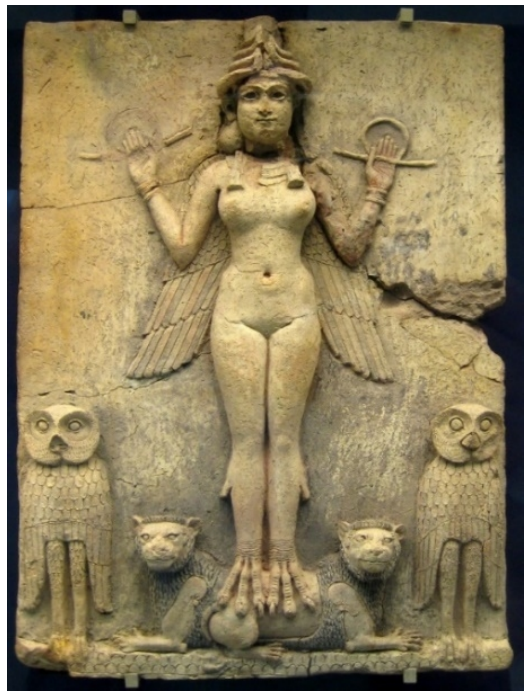

Görsel 1. British müzesi, Tanrıça İnanna (İştar) kabartması

Pagan inançlara sahip olan toplumlar, daha sonraki dönemlerde, Yahudilik veya Hristiyanlık dinlerine geçmeye başlarken; orans duruşu gibi antik inançlarını tümüyle terk etmeyerek, yeni mensubu oldukları dinlerinin içerisinde bu tür gelenekleri şekilsel olarak yaşatmaya çalışmışlardır.

Dua etme biçimleri, Hristiyanlara atalarından miras kalmıştır. Pagan inançlarda birçok dua etme şekli söz konusudur. Bunlardan ayakta durur vaziyette, kollar ise havaya kaldırılmış halde; baş, yere doğru öne eğik şekilde dururken, diz çökmüş veya secde pozisyonuna benzer şekilde olan çeşitli duruşlar, Hristiyanlık dininde uygun görülmüş dua biçimleridir (Sutherland, 2013, s. 41). Dolayısıyla orans, Hristiyanlıkta dua etme duruşlarından sadece tek bir şeklini göstermektedir. Orans duruş, bu anlamda daha çok temsili ve sembolik bir anlam olarak öne çıkmaktadır.

Erken Hristiyanlık döneminde, orans duruşundaki figürlerle; özellikle Roma katakomplarındaki fresk ve kazıma resimlerde karşılaşılmaktadır (Görsel 2). Bu dönemde, henüz Roma'da resmiyet kazanmadığı için yasaklı bir din olan Hristiyanlık, varlığını; bir dönem, Romalıların pagan dönemlerde kullanmış oldukları yer altı mezarları olan katakomplarda sürdürmüştür. Bu nedenle Erken Hristiyan sanatına ait ilk örnekler, bu katakomplarda ortaya çıkmaya başlamıştır.

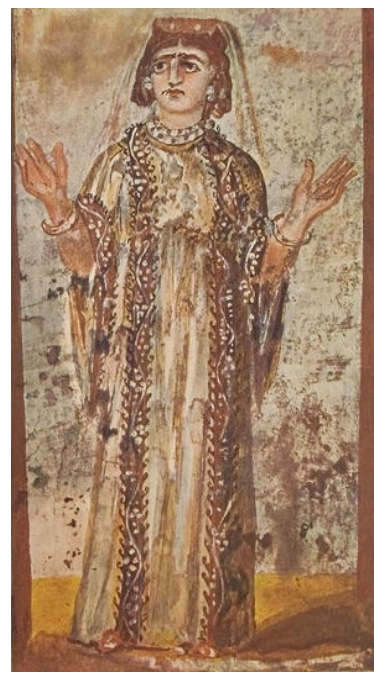

Görsel 2. Jordanians Katakomp’undaki orans duruş pozisyonunda bir kadın freski (Roma, 3. yy.)

Katakomp sahnelerindeki orans duruş sahnelerinden sonra, 5-7. yy. larda, Eski Ahit menşeili orans duruşlu Daniel tasvirleri, Doğu Roma (Bizans) sanatında yer edinmiştir. ${ }^{2}$ Özellikle "Daniel aslanlar ininde" ${ }^{3}$ konulu sahnede,

\footnotetext{
2 Danyal (Arapça: دانيال Danyal', Farsça: دانيال Danial', İbranice: דניאל Danielle', Yunanca: $\Delta \alpha v i \eta ́ \lambda ~ D a n i e l ')$, diğer dillerde Daniel olarak geçmekte, Musevilik, Hristiyanlık ve İslamiyet tarafından peygamber olarak kabul edilmektedir. Kur'an-1 Kerim'de ismi geçmeyen ancak İslami eserlerde bahsedilen peygamberlerden biridir. Detaylı bilgi için Bkz: Erişim adresi: https://tr.wikipedia.org/wiki/Danyal.

${ }^{3}$ Eski Ahit metinlerinde yer alan bu olayda Babil Kralı Darius, nazik ve bilge kişiliğinden dolayı Daniel'i sever ve onu üst bir düzeye getirir. Ancak. Kralın etrafından bazı çevreler, alınan bu karardan rahatsız olmuş ve inançlı Daniel'i aslanlar çukuruna atılması için planlar
} 
kompozisyonun merkezinde; orans duruşunda Daniel, yanındaki aslanlarla ön plana çıkmaktadır. Eski Ahit'teki "Daniel aslanların ininde" kompozisyonu, Erken Hristiyanlık sanatında sembolik olarak Hz. İsa'nın dirilişini ifade etmektedir (Aladashvili, 1977, s. 56-57). Daniel'in mucizesini gösteren ve konusu Eski Ahit dini metinlerine dayalı bu sahnede; Daniel, ellerini yukarı doğru kaldırarak dua eder şekilde tasvir edilmiştir ${ }^{4}$ (Görsel 3).

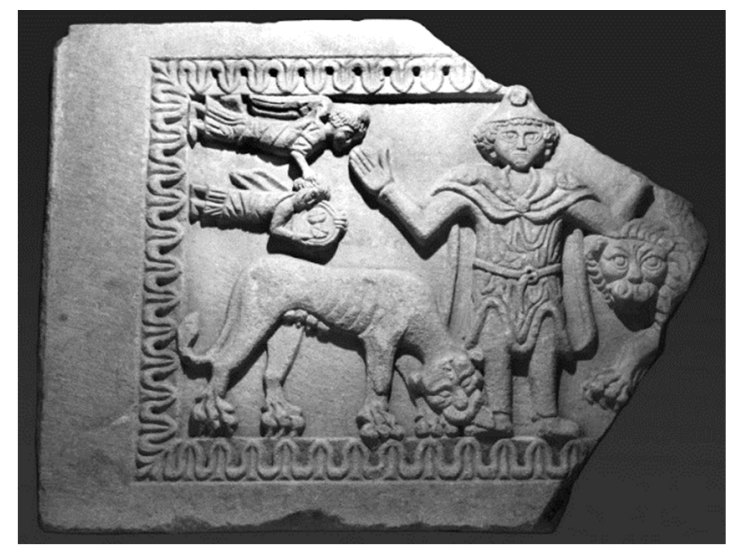

Görsel 3. İstanbul arkeoloji müzesi, "Daniel aslan ininde”, konulu levha (6. yy.)

Orans Duruşlu Daniel sahnelerinin, Doğu Roma sanatında 10-11. yy.'larda, fresk ve mozaik malzeme şeklinde yaygınlık gösterdiği görülmekte ve bu geleneğin sürdürüldüğü anlaşılmaktadır. 10-12. yy. Bizans sikkelerinde, orans duruş pozisyonunda çeşitli figürlere yer verildiği görülmektedir (Görsel 4).

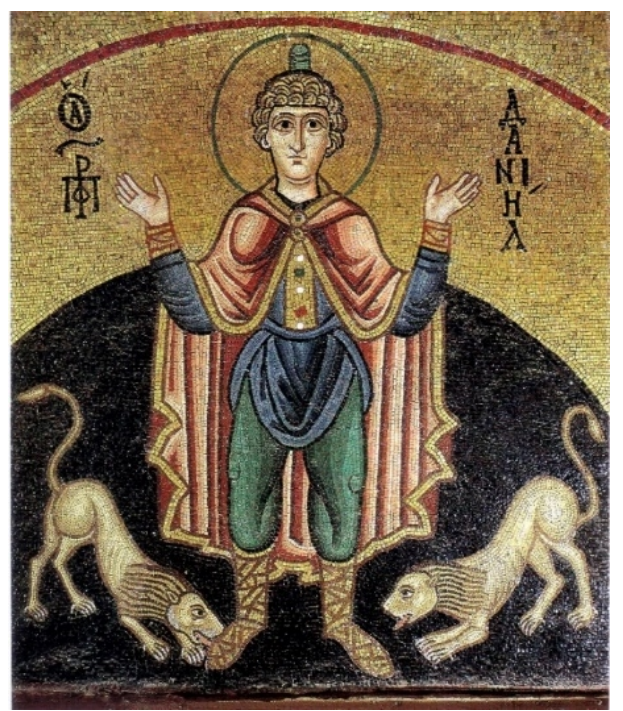

Görsel 4. Daphni (Hosios Loukas) manastırı (Sakız Adası-11-12. yy.)

\section{Yöntem}

Araştırmada Betimsel Yöntem kullanılmıştır. Konu ile ilgili literatür taraması yapılmış olup, ilgili yazılı materyaller tek tek incelenerek analizi yapılmıştır. Araştırma konusuna kaynaklık eden tarihi Tao-Klarceti Bölgesi'ndeki Hristiyan dini mimari yapılarda yerinde gözlem yapılmış ve gözlemin objektif bir biçimde kaydedilmesi sağlanmıştır. Söz konusu dini mimari yapılarda görülen orans duruşlu sahnelerin, din ve sanat arasındaki etkileşimin bir sonucu olan somut yansımaları incelenmiştir.

yapmışlardır. Kralı kullanan bu kişiler, krala bir ay boyunca kraldan başka, hiçbir ilah için ibadet edilmesini yasaklayan bir yasa çıkartırmışlardır. Daniel, yasayı öğrendiği zaman, evine gider ve her zamanki gibi dua eder. Kralın adamları, Daniel'in Yehova'ya (Tanrı) dua etmekten vazgeçmeyeceğini zaten iyi bilmektedirler. Kral Darius, o adamların bu yasayı neden istediklerini öğrenince çok üzülür. Fakat bu yasayı değiştiremez ve de Daniel'in aslanların bulunduğu çukura atılmasını emretmek zorunda kalır. Fakat Daniel'e, "Hizmet ettiğin Tanrı'nın seni kurtaracağını umarım.” der. Darius o kadar üzülür ki, bütün gece uyuyamaz. Ertesi sabah aslanlar çukuruna koşar. Resimde onu görebilirsin. Söyle seslenir: "Yaşayan Tanrı'nın hizmetçisi Daniel! Hizmet ettiğin Tanrın seni aslanlardan kurtarabildi mi?” Daniel, "Tanrı meleğini gönderdi ve bana dokunmasınlar diye aslanların ağzını kapadı.” der. Kral buna çok sevinir. Daniel'in çukurdan çıkarılmasını emreder. Sonra Daniel'den kurtulmak isteyen kötü adamları aslanlara attırır. Onlar daha çukurun dibine varmadan, aslanlar onları kapar ve bütün kemiklerini kırarlar. Sonra kral Darius ülkesindeki bütün halklara mektuplar gönderip, 'herkesin Daniel'in Tanrısına saygı göstermesini emrediyorum. O büyük mucizeler yapar. Daniel'i aslanlara yem olmaktan kurtardı' der. Bkz: Daniel 6:1-28.

${ }^{4}$ Bkz: Kitab-1 Mukaddes Daniel:6. 


\section{Tao-Klarceti bölgesi'ndeki Hristiyan dini mimarisi plastik bezemelerinde orans duruş sahneleri}

Araştırmamıza konu olan ve tarihi kaynaklara göre, Tao-Klarceti olarak bilinen ve Artvin, Erzurum ve Ardahan illerini kapsayan bölge, 8. yy. ın ortalarından, 13. yy. daki Osmanlı hâkimiyetine geçinceye kadar uzun bir süre, I. Aşot tarafından kurulmuş olan Tao-Klarceti Beyliği'nin topraklarını oluşturmuştur (Aytekin, 2018, s. 10). 4. yy. da Tao Klarceti bölgesine yayılmaya başlayan Hristiyanlıkla beraber, bölgedeki mimari doku, sonraki yüzyıllarda bu yeni inanç sitemine göre șekillenmeye başlamıștır. Yeni gelişmeye başlayan dini mimari ile beraber orans duruş gibi çeşitli ikonografik sahneler de, bu mimarinin bezeme programlarına dahil edildiği izlenmektedir.

Tao-Klarceti bölgesindeki Hristiyan dini mimarisi kapsamında ele aldığımız orans duruş sahneleri; Barhal/Parhali (Altıparmak), Oşki /Öşvank (Çamlıyamaç) ve Haholi/Haho (Bağbaşı) manastır kiliselerinde karşıllaşılmaktadır. Bunlardan Barhal ile Haholi kiliselerinde birer adet; Oşki Kilisesi'nde ise, on bir orans duruşlu tasvir tespit edilerek incelenmiştir (Tablo 1).

Tablo 1

Tao-Klarceti bölgesi, orans duruş pozisyonundaki tasvirlerin yer aldığı kiliseler

\begin{tabular}{|c|c|c|c|}
\hline \multicolumn{2}{|c|}{ Yapının Yeri } & \multirow{2}{*}{ Yapının Adı } & \multirow{2}{*}{ Yapının Tarihi } \\
\hline ill & İlçe & & \\
\hline Artvin & Yusufeli & Barhal/Parhali (Altıparmak) Kilisesi & $958-973$ \\
\hline & Tortum & Haholi/Haho (Bağbaşı) Kilisesi & $976-1001$ \\
\hline Erzurum & Uzundere & Oşki /Öşvank (Çamlıyamaç) Kilisesi & $963-973$ \\
\hline
\end{tabular}

Parhali Kilisesi'nin batı cephesinde; eksenin kuzeyinde yer alan pencere kemerinin köșeliğinde, ellerini iki yana açarak orans duruş vaziyetinde küçük sakallı bir adamın ön yüzü görülmektedir (Görsel 5; Görsel 6). Adamın uzun paltosu, ayaklarına kadar erişmektedir. Bu insan figürünün yanındaki yazıtta, Gürcü dilinde yazılmış; "İsa'nın merhameti T(heodor)e'nin üzerine olsun." içerikli bir ibare bulunmaktadır. Alçak kabarma tekniğindeki bu figürün, sade giyiminden dolayı, bu yapının mimarı olabileceği düşünülmektedir (Djobadze, 1992, s. 181).

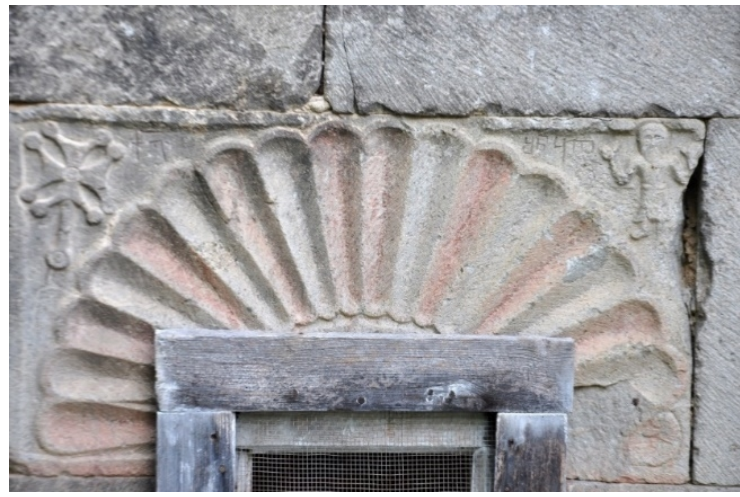

Görsel 5. Barhal/Parhali (Altıparmak) kilisesi, batı cephesi, eksenin kuzeyindeki pencere kemeri

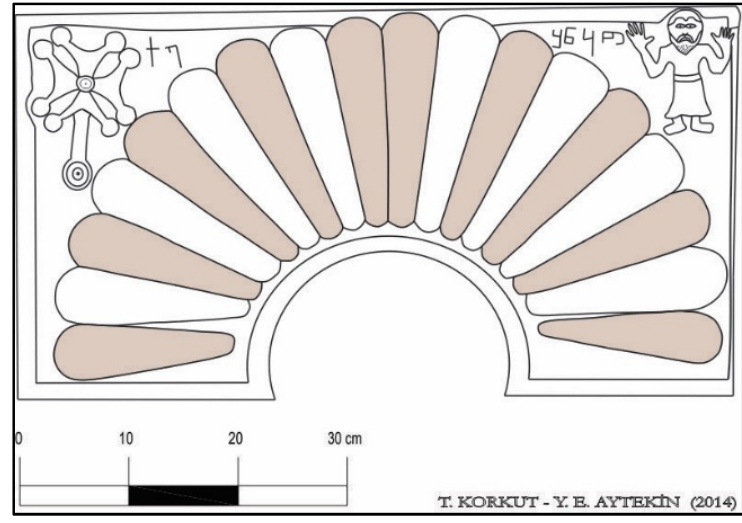

Görsel 6. Barhal/Parhali (Altıparmak) kilisesi, batı cephesi, eksenin kuzeyindeki pencere kemeri

Oşki Kilisesi’nin batı haç kolunun güney cephesindeki saçak silmesinin alt kısmına; aynı hizada ve eşit aralıklarla konumlandırılan üç melek figürünün, orans duruşlu olarak tasvir edildiği anlaşılmaktadır (Görsel 7-8). ${ }^{5}$ Yekpare birer taşa işlenen bu heykelvari meleklerden eksende kalanının ana hatları tamamen tahrip olmuş olmakla beraber,

\footnotetext{
${ }^{5}$ Söz konusu bu meleklerden ortadaki melek tahrip olmuş olsa bile kompozisyonu tamamlayan bu cephedeki diğer melekler ile benzer formda tasvir edildiği düşüldüğü için bu melek figürü de orans duruş vaziyetinde değerlendirilmiștir.
} 
bu meleğin doğu ve batısında kalan diğer iki melek ise, günümüze oldukça sağlam gelebilmiştir. Yüksek kabartma tekniğinde, tam boy olarak, cepheden verilen bu melek figürlerinin kanatları, ayak hizası seviyesine kadar uzatılmıştır. Yapıdaki diğer melek figürlerine oranla, daha kaba bir işçiliğin uygulandığı; bu koruyucu meleklerin daha çok sembolik birer figür olarak tasvir edildikleri anlaşılmaktadır. Doğu tarafta kalan melek figürü; bol dökümlü ve yüzeyi sade elbise içinde tasvir edilmiş ancak baş kısmı ve yüz hatlarının tahrip olduğu görülmektedir. Meleğin ayak kısımlarının olmadığı da, dikkat çeken bir başka önemli nokta olarak göze çarpmaktadır. Batı tarafta bulunan melek de, doğuda kalan melek ile benzer formda tasvir edilmiş ancak, farklı olarak ayak kısımlarının mevcut olduğu görülmektedir. Bu meleklere benzer formda tasvir edilmiş orans duruş pozisyonundaki bir başka melek figürü de, yapının güneybatısında yer alan ek mekanın, batı cephesinin üçgen alınlığında yer almaktadır (Görsel 9-10). Öşki Kilisesi, batı haç kolunun güney cephesindeki üst kısımlar, göklerin hiyerarşisini temsil edenler olarak, koruyucu meleklere ayrılmıştır (Aladashvili, 1977, s. 111).

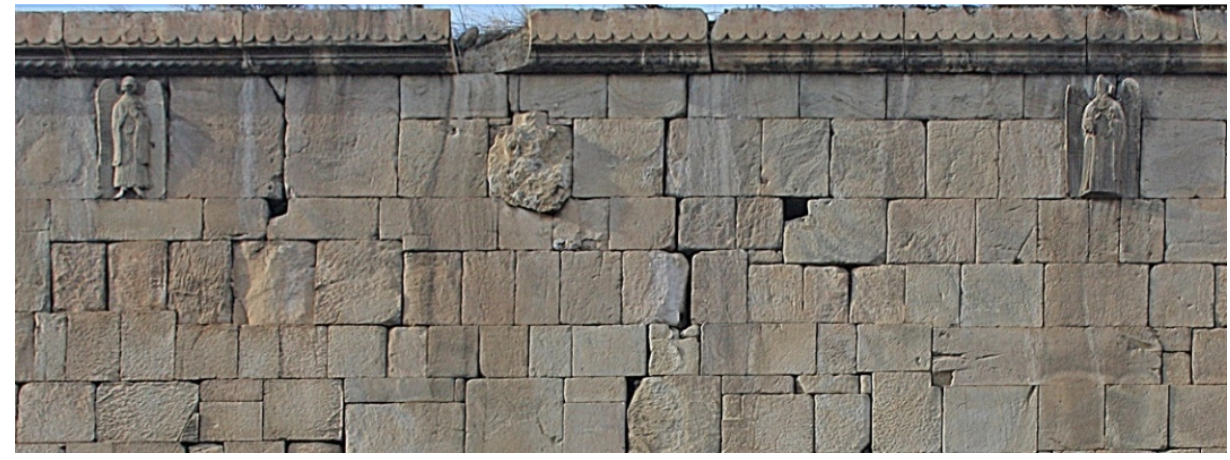

Görsel 7. Oşki /Öşvank (Çamlıyamaç) kilisesi, batı haç kolunun, güney cephesi, melek figürleri

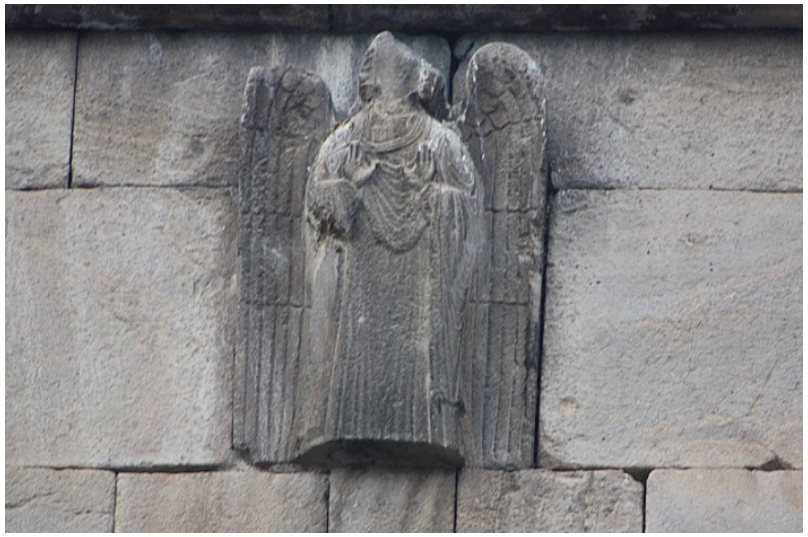

Görsel 8. Oşki /Öşvank (Çamlıyamaç) kilisesi, batı haç kolunun, güney cephesi, eksenin doğusundaki melek

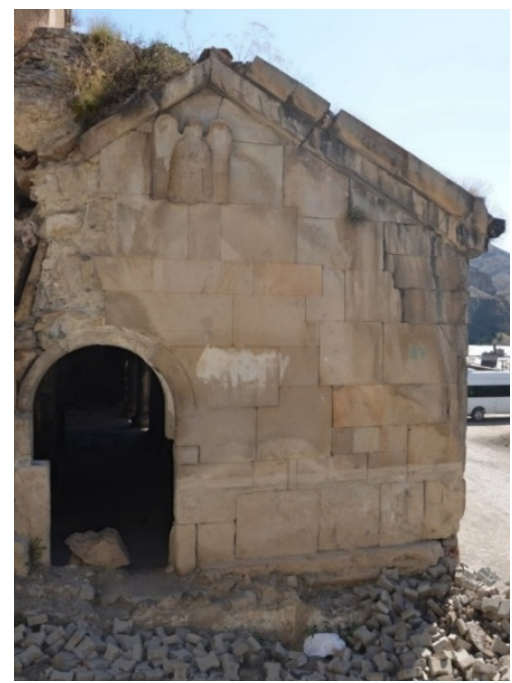

Görsel 9. Oşki /Öşvank (Çamlıyamaç) kilisesi, güneybatı ek mekân, batı cephe 


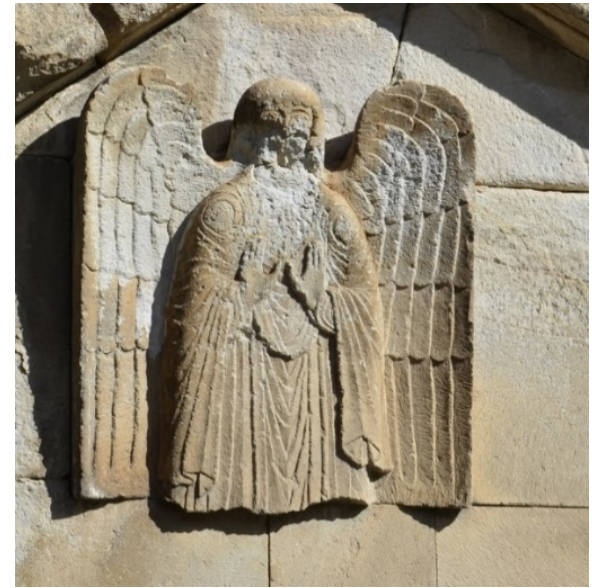

Görsel 10. Oşki /Öşvank (Çamlıyamaç) kilisesi, güneybatı ek mekân, batı cephesindeki melek figürü

Oşki Kilisesi'nin batı cephesindeki ikiz pencerenin üst kısmında yer alan Aziz (Sütuncu) Simeon ${ }^{6}$ figürünün, orans duruş pozisyonunda işlendiği dikkat çekmektedir. Buradaki pencere alınlığ stilize bitkisel motifin üzerine oturan ve altlı-üstlü üç basamaklı başlık ve kaidesi bulunan bir büst üzerinde, Aziz Simeon figürü yer almaktadır. Aziz Simeon, dini bir kıyafete bürünmüş olarak verilmiş olup, omuz kısmındaki pelerinin konturları görülebilmektedir. Azizin haleli başına, koukoulion ${ }^{7}$ tarzında bir şapka taktığı seçilebilmekte ve yüzünün büyük bir bölümü tahrip olmakla beraber, gür sakalı belirgindir. Göğsünün üstünde de, iki eşit kollu haç bulunmaktadır (Görsel 11). Aziz Simeon'a ait olduğu düşünülen orans duruşundaki bir başka figür de, kilisenin güneybatı ek mekânda bulunan sekizgen gövdeli sütun başlığının üstünde yer almaktadır (Görsel 11) (Winfield, 1968, s, 54). Yüksek kabartma tekniğindeki bu figürün, baş kısmı tahrip olduğu için yüz hatları anlaşılamamaktadır. Kıvrımlı pelerinin göğüs seviyesi hizasında, eşit kollu bir haç yer almaktadır. Aziz Simeon büstünün oturduğu bu sütun başlığının yüzeyi, orans duruş vaziyetinde iki melek melek figürü ile bezenmiştir. Uçma pozisyonundaki bu meleklerin kanatları; eksende dik ve simetrik bir şekilde yan yana işlenmiştir. Omuzlarında, aşağı doğru sarkan birer pelerin bulunan bu melek figürleri, alçak kabartma tekniğinde tasvir edilmiştir (Görsel 12).

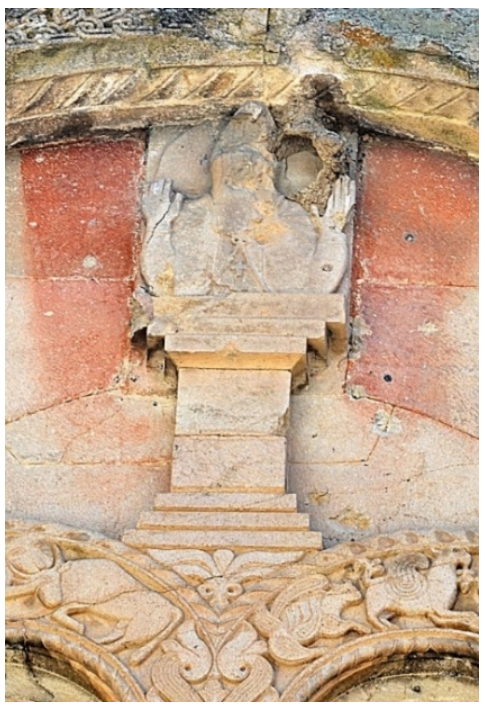

Görsel 11. Oşki /Öşvank (Çamlıyamaç) kilisesi, batı cephesi, Aziz Simeon figürü

\footnotetext{
${ }^{6}$ Ortodoks Kilisesi'nin önemli din adamlarından biri olan Aziz (Sütuncu) Simeon, 390 yılında, Siron ve Kilikon bölgeleri arasında bulunan Sisan köyünde (Kozan/Adana) dünyaya gelmiștir. 36 yıl boyunca Halep (Suriye) yakınlarındaki bir kilisenin avlusunda bulunan bir sütun üzerinde yaşamıştır. Detaylı bilgi için Bkz: Torrey, C. C., 1899, s. 253-276; Tiefenbach H., 2012, s. 269-275.

${ }^{7}$ Koukoulion, Doğu Ortodoks Kilisesi'nde yüksek dereceli rahipler tarafından giyilen geleneksel başlık. Detaylı bilgi için Bkz: Kazhdan, 2005, s. 1155.
} 


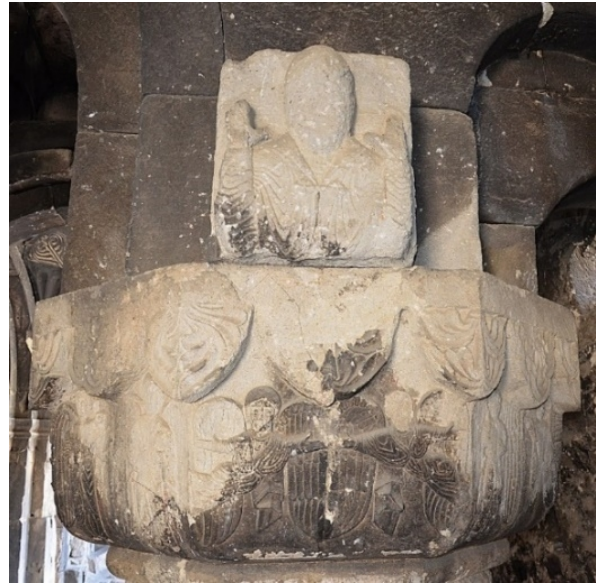

Görsel 12. Oşki /Öşvank (Çamlıyamaç) kilisesi, güneybatı ek mekân, Aziz Simeon figürü ve melek figürleri

Güneybatı ek mekandaki bu söz konusu sütunun gövde yüzeyinde Azize Nino olduğu düşünülen orans duruş pozisyonunda, küçük ölçekli bir kadın figürü yer almaktaydı. Günümüzde sütun gövdesinin bu kısmı tahrip olmuştur. Ancak, araştırmacıların figürlerde bu tahribat olmadan önce çektikleri ve figürlerin orijinal durumlarını gösteren fotoğraflar incelendiğinde; burada, kabaca vücut hatları anlaşılabilen ve başının örtülü olmasıyla; azizelere mahsus geleneksel kıyafet içinde bir kadın tasvirinin olduğu anlaşılmaktadır (Görsel 13). ${ }^{8}$

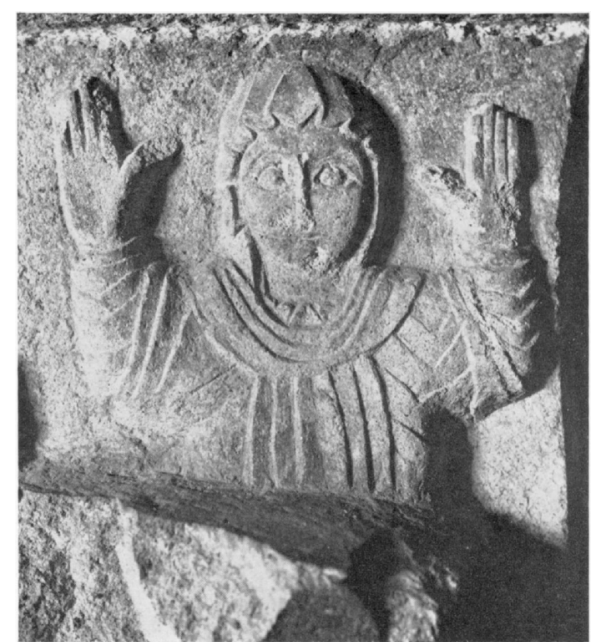

Görsel 13. Oşki /Öşvank (Çamlıyamaç) kilisesi, güneybatı ek mekândaki, sekizgen gövdeli sütun, batı gövde yüzeyi, Azize Nino figürü

Oşki Kilisesi'nde, 2003 yılında yapılan kaçak bir kazı sonucu ele geçirilen ve daha sonra Erzurum Müzesi'nde sergilenen iki yekpare taşın yüzeyinde; orans duruş pozisyonunda, Bagratlı krallarından Kral David ve Kral Bagrat'ın figürleri yer almaktadır (Görsel 14; Görsel 15). ${ }^{9}$ Üstten üçgen bir alınlıkla son bulup yuvarlak bir kemerle sınırlanan bu taşların ön yüzeylerinde; altlı-üstlü yerleştirilen, alçak kabartma tekniğinde yapılmış, figürler yer almaktadır. Taşların yan yüzeyleri ise, kitabelerle bezenmiştir. $155 \mathrm{~cm}$ yüksekliğindeki taş bloğun ön yüzünde; üst kısımda Hz. Meryem ve çocuk Hz. İsa'nın rölyefi, onların hemen altına bitişik konumda orans duruş vaziyetinde Kral David figürü yer almaktadır. Taşın sol yan yüzeyinde yazıtlardan; alttaki bu figürün, Gürcü kralı David olduğu anlaşılmaktadır (İşler, 2006, s. 270). Cübbeli ve sakallı olarak gösterilen kralın kıyafeti, eşkenar dörtgen ve dairesel yoğun geometrik motiflerle hareketlendirilmiş ancak, asimetrik bir düzende yerleştirilmişlerdir. 130 cm. yüksekliğinde ve öncekiyle benzer formdaki diğer taşın yüzeyinde ise; üstte Vaftizci Yahya ve onun altında orans duruş pozisyonunda Kral Bagrat'ın tasvir edildiği, taş üzerindeki kitabelerde belirtilmiştir (İşler, 2011, s. 302). Hz. Yahya, sağ elinde bir haç tutar şekilde, uzun saçlı, gür sakallı ve başı haleli olarak betimlenmiştir. Figürler, büst şeklinde belden yukarı ve cepheden verilmiştir. Bu taşlardan birinin yan yüzeyinde "Tanrının oğlu

\footnotetext{
8 Takaşvili ve Winfield'ın çözümlediği yazıtlara göre, bu figürde Azize Nino'nun tasvir edildiğini belirtmektedir. Bkz. Winfield, 1968 , s, 54 Kartli'nin (Gürcistan'ın) 4. yy.'da Hıristiyanlaşmaya başlaması ve Hıristiyanlığın Artvin bölgesine kadar yayılması, Kapadokya kökenli Azize Nino ile ilişskilendirilmektedir. Detaylı bilgi için Bkz: Vaçnadze, vd., 2003, s. 7.

${ }^{9}$ Yapının cami olarak kullanılacağı dönemde yapılan değişikliklerle örülen duvar içinde kalmış iki yekpare taş, kilisede 2003 yılında yapılan kaçak bir kazıda yerinden sökülmüștür. (Bkz: İșler, 2006, s. 270.) Ele geçirilen bu eserler günümüzde Erzurum Müzesi’nde sergilenmektedir.
} 
İsa, kutsal vaftizcinin yardımı ile senin kulların olan ve bizim krallarımız, Adernese Kuroplat'ın oğulları, bu kutsal kiliseyi inşa eden Bagrat ve Davit’i bağışla.” ibaresi yer almaktadır (İşıler, 2006, s. 270).
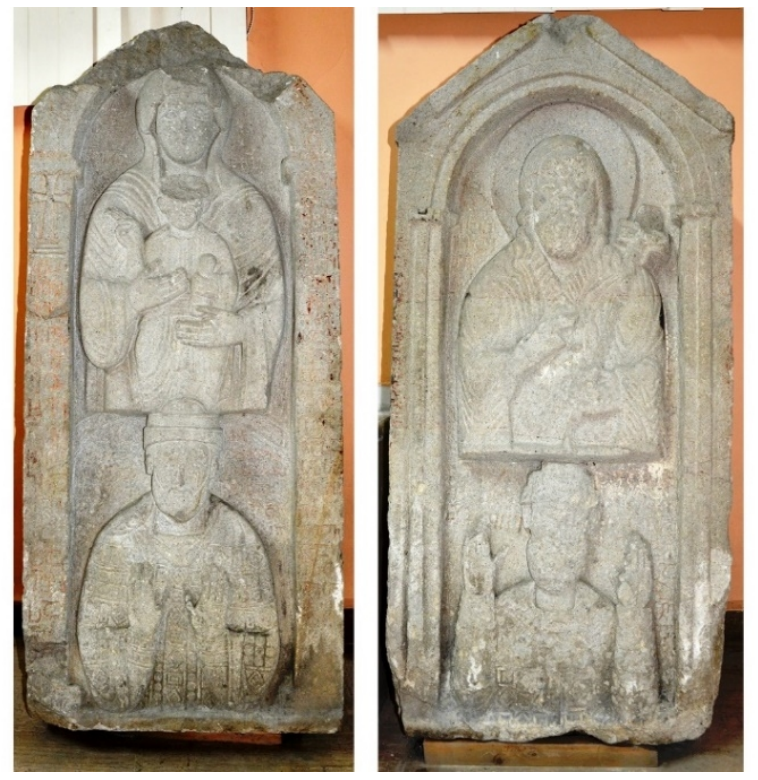

Görsel 14. Sol üst Hz. Meryem ve Çocuk İsa, sol alt Kral David figürü; Sağ üst Aziz Yahya, sağ alt Kral Bagrat figürü

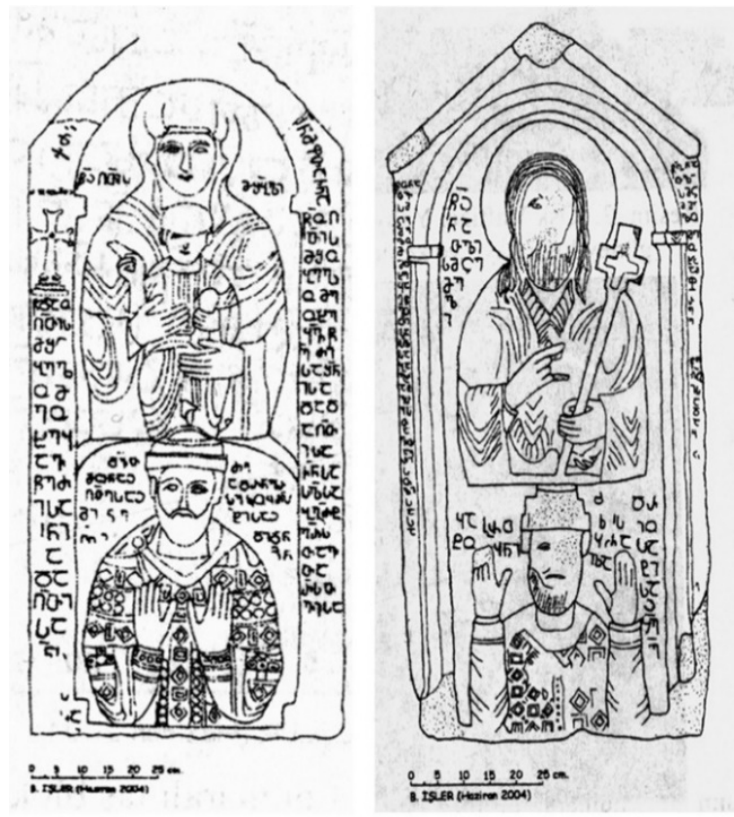

Görsel 15. Sol üst Hz. Meryem ve Çocuk İsa, sol alt Kral David figür çizimi, Sağ üst Aziz Yahya, sağ alt Kral Bagrat figür çizimi

Bölgede tespit edebildiğimiz son orans sahnesi, Haholi/Haho (Bağbaşı) Kilisesi'nin güney cephesinde yer alan kapının yan cephesindeki "Yunus Peygamber'in denize atılması" sahnesinde yer almaktadır (Görsel 16). ${ }^{10}$ Sahnenin bir bölümünde Hz. Yunus, elleri açık bir şekilde orans pozisyonunda, köpek balığına benzeyen, sivri ve keskin dişleri ile dikkat çeken bir balığın ağzından dışarı doğru çıkar vaziyette tasvir edilmiştir. ${ }^{11}$

\footnotetext{
${ }^{10}$ Buradaki sahnede sanatçı, gerçekte pişmanlık duymayı ifade eden Hz. Yunus tasvirini mi, orans pozisyonunda gösterdiği ya da Hz. Yunus’un balığın ağZından çıkarken ki doğal duruşunu mu ifade etmeye çalıştığı konusu tam netlik kazanmamıştır.

${ }^{11}$ Burada arslan başlı ve iki ayağı kısa, efsanevi bir yaratık olan "Cetus/Ketos" adlı bir deniz yaratığından da bahsedilebilir. Detaylı bilgi için Bkz: Korkut, 2018, s. 184-185.
} 


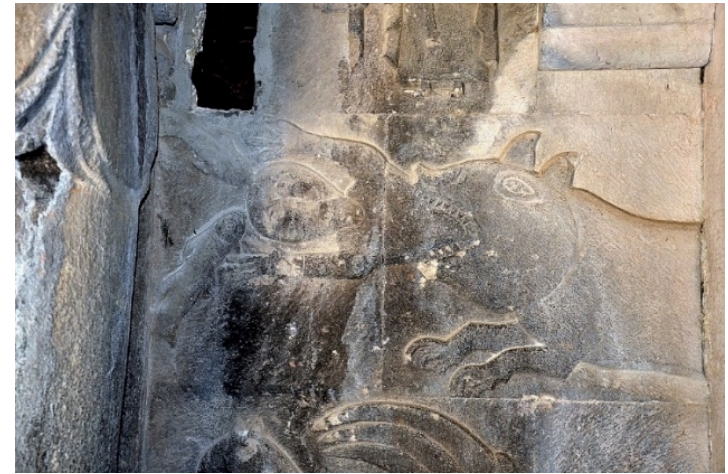

Görsel 16. Haholi/Haho (Bağbaşı) kilisesi, güney cephe, portalin doğu kanadında yer alan “Hz. Yunus'un Denize Atılma Sahnesi”

\section{Değerlendirme ve sonuç}

Orans duruş terimi; her ne kadar bir Hristiyan geleneği olarak algılansa da pagan inanç kültürlerinde de benzer biçimde çeşitli dua etme şekillerinin olduğu anlaşılmaktadır. Pagan inançlara sahip olan toplumlar, daha sonraki dönemlerde, Yahudilik veya Hristiyanlık dinlerine geçerken; orans duruşu gibi antik inançlarını tümüyle terk etmeden, benimsemiş oldukları yeni dinlerinin içerisinde bu tür gelenekleri şekilsel olarak yaşatmaya çalışmışlardır. Günümüzde Afyon Müzesi'nde teşhir edilen ve Bizans dönemine tarihlenen bir levhada orans duruş tarzında çıplak bir kadın sahnelenmiştir. Memelerini yılanların emdiği bu tasvir, Hristiyanlıktan ziyade, pagan inanç etkisini gösteren ilginç bir örnek olarak değerlendirilebilir (Görsel 17; Görsel 18).

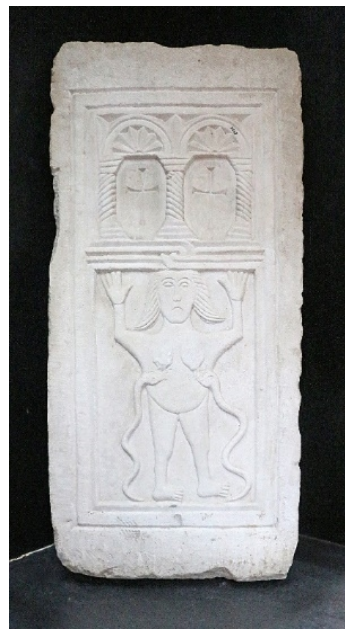

Görsel 17. Afyon müzesi, Orta Bizans dönemi’ne ait bir levha

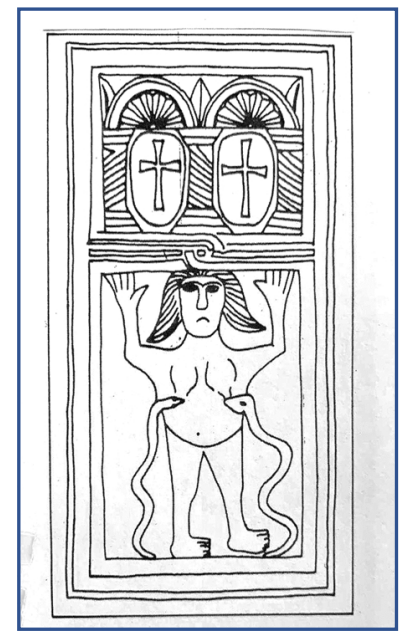

Görsel 18. Afyon müzesi, Orta Bizans dönemi’ne ait levhanın çizimi

Erken Hristiyan sanatında, katakomplarla görülmeye başlayan orans duruş, 5-6. yy. da; Eski Ahit metinlere dayanan Daniel sahneleriyle yaygınlık göstermiş ve bu duruş gelenekselleşerek daha sonraki yüzyıllarda da sürdürülmüştür. Erken Hristiyan sanatında, Hz. İsa'nın dirilişini ifade eden "Daniel aslanlar inindeki" kompozisyon bir anlamda; Hristiyan dininin zaferini temsil etmektedir.

Araştırma kapsamında tarihi Tao-Klarceti Bölgesi, mimari plastiğinde yapılan incelemelerde, taş malzeme ile yapılmış toplamda onbir adet orans duruş pozisyonunda sahne tespit edilmiş ve incelenmiştir. Bunlardan Parhal ile Haholi kiliselerinde birer adet; Oşki Kilisesi'nde ise, dokuz adet orans duruşlu tasvir yer almaktadır. Parhal Kilisesi'nde; bir bani orans duruşlu olarak tasvir edilmiş, Haho Kilisesi’nde; Hz. Yunus tasviri orans duruşlu olarak verilmiş ve Öşki Kilisesi'nde ise, altı koruyucu melek, Azize Nino, Aziz Simeon, Kral Bagrat ve Kral David tasvirleri orans duruş şeklinde tasvir edilmiştir. Bunların dışında, Artvin'de bulunan ve 10. yy. 1n ortalarına tarihlenen Opiza (Bağcılar) Manastır Kilisesi'nden günümüze ulaşan iki yekpare taştan birinin yüzeyinde, tahtta oturan Hz. İsa ve onun sağında da dua eder vaziyette Gürcü krallarının soylarını dayandırdıkları Hz. Davut peygamberin tasviri görülmektedir (Aladashvili, 1977, s. 65). Hz. Davut, să̆ eliyle orans duruşu şeklinde kaldırırken; sol eliyle de Hz. İsa'yı işaret eder vaziyette yönlendirmiş olarak görülmektedir. Kompozisyonu oluşturan diğer yekpare taşın yüzeyinde ise I. Aşot, elinde tuttuğu kilise maketini uzatır şekilde tasvir edilmiştir. ${ }^{12}$

${ }^{12}$ Bağcılar Manastırı'nın güney cephesinden, I. Dünya Savaşı sonrasında sökülerek götürülen bu kabartmalar, günümüzde Tiflis Devlet Müzesi'nde sergilenmektedir. 
Bu figürlerin kim oldukları, başları ve ayak kısımlarındaki yüzeylere yazılmıştır. Bu sahnedeki tasvirde, ellerin ve başların büyük olarak vurgulanmış olmasından dolayı; figürlerde orantısılıklar göze çarpmaktadır. Bu kabartma, alçak kabartma yöntemiyle yapılmış ve yanlardaki figürlerin baş ve gövdeleri cepheden, ancak ayakları profilden verilmiştir (Görsel 19).

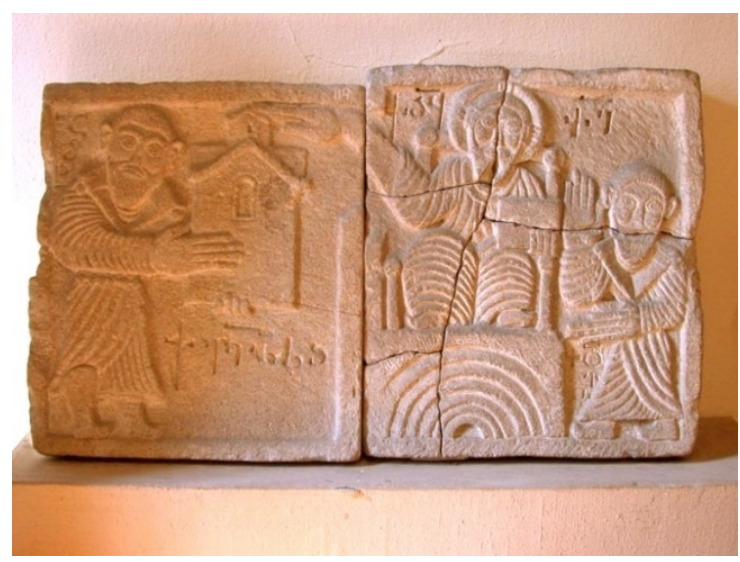

Görsel 19. Opiza (Bağcılar) Kilisesi, "Takdim sahnesi”

Oşki'de, özellikle cephelerin üst kısımlarına yerleştirilen ve Hristiyan inancında insanları koruduklarına inanılan melek figürlerinin orans duruş vaziyetinde tasvir edildikleri dikkat çekmektedir. Mikail, Cebrail ve diğer melekler gibi belirleyici özellikleri bulunmayan bu melekler, hiyerarşinin son melekleri insanları korumakla görevli ve insana en yakın melekler olarak gruplandırılmışlardır (Korkut, 2018, s. 278-281). Yüksek kabartma tekniğinde işlenen bu melek figürlerinin, özellikle kilise ana kapısının yer aldığı güney cephesinde konumlandırılması, kiliseye gelen ziyaretçiler tarafından dua eder vaziyetteki meleklerin görülmesine önem verildiğini göstermektedir.

Melekler dışında, Ortodoks Kilisesi’nin önemli din adamlarından Aziz Simeon (385-390) ve Tao-Klarceti Bölgesi’ne 4. yy. da Hristiyanlığ 1 yayan Kapadokya kökenli Azize Nino (280-332) gibi sayılı kişilerin, kayda değer görülerek orans duruş vaziyetinde tasvir edildikleri görülmektedir. Aziz ve azize gibi kutsal görülen kişilerin yanı sıra, Kral Davit ve Kral Bagrat'a ait taş kabartmaların da orans vaziyetinde işlenmesi, Bagratlıların, bu geleneğe büyük önem verdiğini göstermektedir.

Komşu sanat çevresi kapsamında, Doğu Anadolu Bölgesi'ndeki Hıristiyan mimarisinde bulunan plastik bezeme programlarında, ender de olsa orans duruşlu tasvirler ile karşılaşmak mümkündür. Orans duruş tasvirlerinin görüldüğ̈̈ bu ender yapılardan birisi Ermenilere ait yapılarından biri olan Akdamar Adası'ndaki Holly Cross (Kutsal Haç) Kilisesi'dir (915-921). Kilisenin batı haç kolu cephesinde; orans duruşlu bir serafim ${ }^{13}$ figürü, batı haç kolunun kuzey cephesinde yer alan "Daniel Aslanlar İninde" sahnesinde; Daniel ile onunla zindana atılan Hananya, Mişael ve Azarya ve Vaftizci Yahya orans duruşlu olarak sergilenmiştir (Görsel 20).

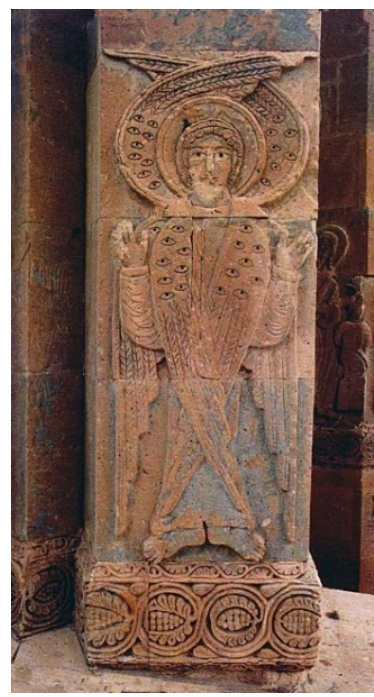

Görsel 20. Akdamar (Kutsal Haç) kilisesi, Batı haç kolu, Serafim figürü

\footnotetext{
${ }^{13}$ Serafim/Seraphim:Eski Ahit'e göre; İşaya'nın Tanrı'nın tahtının önünde duruyor şekilde gördüğü altı kanatlı doğa üstü varlıklar. (İşa. 6:27). Bkz: Gündüz,2017, s. 438.
} 
Orans duruş sahneleri, Gürcistan'da Ortaçağ dönemine tarihlenen; katedral, manastır ve kiliselerde, çok yaygın olmasa da görülebilmektedir. Gürcistan'ın Akhalkalaki Bölgesi'ndeki Kumurdo Kilisesi'nin (10. yy.) güney cephesindeki kemer köşeliklerinde, karşılıklı olarak yerleştirilen, orans duruşlu melek tasvirleri dikkat çekmektedir. Başları haleli, meleklerin kanat kısımlarındaki kabartmaların aşınmasıyla, hatlar kaybolmuştur (Görsel 21). Martvili Bölgesi’ndeki Martvili Kilisesi'nin (5-7. yy.) batı cephesindeki frizde "Daniel aslanlar ininde" konulu sahnede, Daniel'in duruşu orans pozisyonunda işlenmiştir (Görsel 22). Erken Hristiyanlık Dönemi’nde yaygın olan bu Eski Ahit konulu sahnenin; Gürcistan'daki dini mimaride de benzer bir şekilde uygulandığı gözlenmektedir.

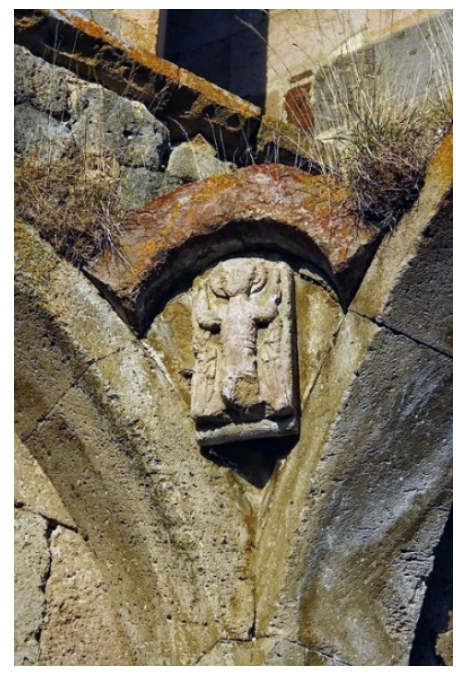

Görsel 21. Gürcistan-Kumordo kilisesi, güney cephesindeki kemer detay1

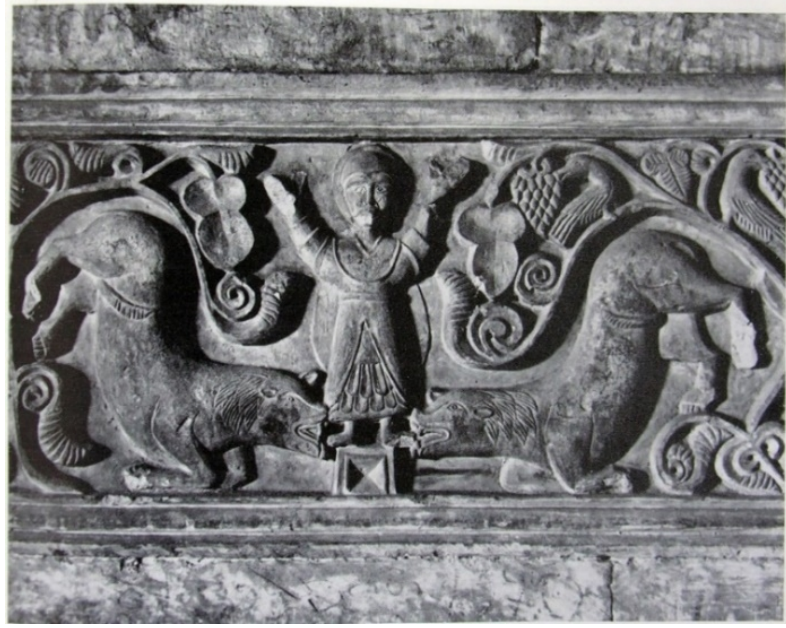

Görsel 22. Gürcistan-Martvili kilisesi, Batı cephesindeki frizin Güney bölümünde, Daniel aslanların ininde

Başlangıçta pagan inança sahip olan Bagratlılar, Hristiyanlık dinini kabul etmeye başladıktan sonra, dinsel öğretilerini ve geleneklerini güçlü sınır komşuları olan Doğu Roma (Bizans) Devleti'nin Ortodoks inancından almaya başlamışlardır. Örneğin, Doğu Roma Hristiyan inancında önemli din adamlarından biri olan Aziz Simeon, Öşki Kilisesi'nin hem batı cephesi ekseninde, bir sütun üzerinde yüksek bir konumda; hem de bu yapının en yoğun bezemeli taşıyıcı unsuru olan güney batı ek mekandaki sekizgen gövdeli sütunun, sütun başlığının üstünde mevcut bulmuştur.

Doğu Roma sanatında katakomplardaki kadın figürleri ve Daniel sahneleri gibi çeşitli kompozisyonlardan gelişen orans duruş geleneği, kendini Tao-Klarceti Bölgesi dini mimarisinde; melek, aziz, azize, bani ve usta kabartmaları gibi farklı figüratif şekillerde anlamlandırılmaya çalışmıştır. Söz konusu kabartmalar, dönemin sanat üslubu özelliklerini yansıtmaktadır. Tespit edilen orans duruşlu bu önemli figüratif kabartmaların büyük çoğunluğunun, Oşki Manastır Kilisesi'nde toplanması bu kilisenin sadece bölgesel değil, Gürcü sanatı açısından genel olarak ayrı bir öneme sahip olduğunun bir göstergesi olarak değerlendirilebilir. 


\section{Kaynakça}

Aladashvili, N. (1977). Gürcistan'da mimari bezeme (5-11. yüzyılların figürlü kabartmalarl). Moskova: Monuments of Ancient Art.

Aytekin, O. (2018). Taşların hikâyesi (2007-2016 Şavşat Kalesi kazı çalışmaları. Ankara: Şavşat Belediyesi Kültür Yayınları.

Danyal (t.y.). Wikipedia içinde. Erişim adresi: https://tr.wikipedia.org/wiki/Danyal

Djobadze, W. Z. (1992). Early Medieval Georgian Monasteries in historic Tao Klarjet'i and Savset'i. Stuttgart: F. Verlag Steiner.

Gündüz, Ş. (2017). Din ve inanç sözlüğü. İstanbul: Vadi Yayınları.

İşler, B. (2006). Öşk Vaftizci Yahya Kilisesi’nde ortaya çıkarılan süslemeli iki taş. H. Gündoğdu, A.A. Bayhan, H. Yurttaş, H. Özkan, Z. Köşklü, H. Özyurt Özcan, M.S. Bayraktar, Ş. Tali (Ed.), IX. Ortaçağ ve Türk Dönemi Kazıları ve Sanat Tarihi Araştırmaları Sempozyumu Bildiriler Kitabı (s. 269-275) içinde. Erzurum: Atatürk Üniversitesi Yayınları.

İşler, B. (2011). Gürcü dinsel mimarisinde Bani tasvirli taş kabartmalar. N. Türker, G. Köroğlu, Ö. Deniz (Ed.), I. Uluslararası Karadeniz Kültür Kongresi Bildiriler Kitabı (s. 299-309) içinde. Sinop: Karabük Üniversitesi Yayınlar1.

Kazhdan, A. P. (2005). The Oxford dictionary of Byzantium. London: Oxford University Press.

Korkut, T. (2018). Artvin ve Erzurum'daki Gürcü dini mimarisinde süsleme. İstanbul: Hiperyayın.

Köroğlu, K. (2015). Eski Mezopotamya tarihi: tarihi başlangıçtan Perslere kadar. İstanbul: İletişim Yayınları.

Özdemiroğlu, A. Ö. (2010). Orans duruş geleneği. Arkeoloji ve Sanat Dergisi, 134, 100-105.

Rona, Z. (1997). “Orans” Mad. Eczacıbaşı Sanat Ansiklopedisi, Cilt: 3. İstanbul: Yapı-Endüstri Merkezi Yayınları.

Sutherland, R. J. (2013). Prayer and piety: the Orans-figure in the Christian Catacombs of Rome (Doctoral dissertation). Université d'Ottawa/University of Ottawa. Erişim adresi: https://ruor.uottawa.ca/bitstream/10393/24259/1/Sutherland_Reita_2013_thesis.pdf

Tiefenbach, H. (2012). Anadolu'nun azizleri. İstanbul: Arkeoloji ve Sanat Yayınları.

Winfield, D. (1968). Some early Medieval figure sculpture from North-East Turkey. Journal of the Warburg and Courtauld Institutes, 31, 33-72. Erişim adresi: https://www.jstor.org/stable/i230442

Torrey, C. C., \& Simeon, S. (1899). The letters of Simeon the stylite. Journal of the American Oriental Society, 20, 253-276.

Vaçnadze, M., Guruli, V., \& Bahtadze, M. (2003). Gürcistan tarihi. Tiflis: Artanuci Yayınları.

\section{Görsel Kaynakçası}

Görsel 1. Tahsin Korkut şahsi arşivi. British Müzesi, Tanrıça İnanna (İştar) kabartması

Görsel 2. Jordanians Katakomp'undaki orans duruş pozisyonunda bir kadın freski (Roma, 3. yy.). Erişim adresi: https://vhoagland.wordpress.com/2016/06/07/the-cross-in-early-christian-art/

Görsel 3. İstanbul Arkeoloji Müzesi, "Daniel Aslan ininde", konulu levha (6. yy.) Erişim adresi: https://www.flickr.com/photos/roger_ulrich/5962424496.

Görsel 4. Daphni (Hosios Loukas) Manastırı (Sakız Adası-11-12. yy.). Erişim adresi: https://upload.wikimedia.org/wikipedia/commons/2/27/Hosios_Loukas_\%28diakonikon\%29_Daniel in the lions\%27 den 01.jpg.

Görsel 5. Tahsin Korkut şahsi arşivi. Barhal/Parhali (Altıparmak) Kilisesi, batı cephesi, eksenin kuzeyindeki pencere kemeri

Görsel 6. Tahsin Korkut şahsi arşivi. Barhal/Parhali (Altıparmak) Kilisesi, batı cephesi, eksenin kuzeyindeki pencere kemeri

Görsel 7. Tahsin Korkut şahsi arşivi. Oşki /Öşvank (Çamlıyamaç) Kilisesi, batı haç kolunun, güney cephesi, melek figürleri

Görsel 8. Tahsin Korkut şahsi arşivi. Oşki /Öşvank (Çamlıyamaç) Kilisesi, batı haç kolunun, güney cephesi, eksenin doğusundaki melek 
Görsel 9. Tahsin Korkut şahsi arşivi. Oşki /Öşvank (Çamlıyamaç) Kilisesi, güneybatı ek mekân, batı cephe

Görsel 10. Tahsin Korkut şahsi arşivi. Oşki /Öşvank (Çamlıyamaç) Kilisesi, güneybatı ek mekân, batı cephesindeki melek figürü

Görsel 11. Tahsin Korkut şahsi arşivi. Oşki /Öşvank (Çamlıyamaç) Kilisesi, batı cephesi, Aziz Simeon figürü.

Görsel 12. Tahsin Korkut şahsi arşivi. Oşki /Öşvank (Çamlıyamaç) Kilisesi, güneybatı ek mekân, Aziz Simeon figürü ve melek figürleri

Görsel 13. Oşki /Öşvank (Çamlıyamaç) Kilisesi, güneybatı ek mekândaki, sekizgen gövdeli sütun, batı gövde yüzeyi, Azize Nino figürü. Kaynak: Winfield, D. (1968). Some early Medieval figure sculpture from NorthEast Turkey. Journal of the Warburg and Courtauld Institutes, 31, 33-72. Erişim adresi: https://www.jstor.org/stable/i230442

Görsel 14. Tahsin Korkut şahsi arşivi. Solda; üstte, Hz. Meryem ve Çocuk İsa, altta; Kral David figürü, Sağda; üstte, Aziz Yahya, altta; Kral Bagrat figürü

Görsel 15. Solda; üstte, Hz. Meryem ve Çocuk İsa, altta; Kral David figürü, Sağda; üstte, Aziz Yahya, altta; Kral Bagrat figürü. Kaynak: İşler, B. (2006). Öşk Vaftizci Yahya Kilisesi'nde ortaya çıkarılan süslemeli iki taş. H. Gündoğdu, A.A. Bayhan, H. Yurttaş, H. Özkan, Z. Köşklü, H. Özyurt Özcan, M.S. Bayraktar, Ş. Tali (Ed.), IX. Ortaçağ ve Türk Dönemi Kazıları ve Sanat Tarihi Araştırmaları Sempozyumu Bildiriler Kitabı (s. 269). Erzurum: Atatürk Üniversitesi Yayınları.

Görsel 16. Tahsin Korkut şahsi arşivi. Haholi/Haho (Bağbaşı) Kilisesi, güney cephe, portalin doğu kanadında yer alan "Hz. Yunus'un Denize Atılma Sahnesi"

Görsel 17. Tahsin Korkut şahsi arşivi. Afyon Müzesi, Orta Bizans Dönemi’ne ait bir levha.

Görsel 18. Afyon Müzesi, Orta Bizans Dönemi’ne ait levhanın çizimi. Kaynak: Parman, E. (2002). Ortaçağda Bizans döneminde Frigya (Phrygia) ve bölge müzelerindeki Bizans taş eserleri (s. 142). Eskişehir: Anadolu Üniversitesi Yayınlar1.

Görsel 19. Opiza (Bağcılar) Kilisesi, "Takdim sahnesi”. Kaynak: İşler, B. (2011). Gürcü dinsel mimarisinde Bani tasvirli taş kabartmalar. N. Türker, G. Köroğlu, Ö. Deniz (Ed.), I. Uluslararası Karadeniz Kültür Kongresi Bildiriler Kitabı (s. 299). Sinop: Karabük Üniversitesi Yayınları.

Görsel 20. Akdamar (Kutsal Haç) Kilisesi, Batı haç kolu, Serafim figürü. Kaynak: Sarafian, A., \& Köker, O. (2010). Ahtamar, Ortaçă̆ Ermeni mimarlı̆̆ının mücevheri. İstanbul: Bir Zamanlar Yayıncılık.

Görsel 21. Tahsin Korkut şahsi arşivi. Gürcistan-Kumordo Kilisesi, güney cephesindeki kemer detay1

Görsel 22. Gürcistan-Martvili Kilisesi, batı cephesindeki frizin güney bölümünde, Daniel Aslanların İninde. Kaynak: Aladashvili, N. (1977). Gürcistan'da mimari bezeme (5-11. yüzyılların figürlü kabartmaları). Moskova: Monuments of Ancient Art. 